\title{
ON SOME FOSSIL FISHES FROM THE DIAMOND-BEARING PIPES OF KIMBERLEY.
}

\author{
By R. Broom, M.D.
}

(Plates XX.-XXII.)

(Received May 26, 1913. Read July 16, 1913.)

The strata surrounding the Kimberley group of mines consist of the upper Dwyka shales, denudation having removed from this area all the higher strata such as are found immediately to the east, between Kimberley and Bloemfontein.

The missing horizons consist of the Ecca beds, that is, of soft blue and greenish shale and flag-stones approximately 2,000 feet thick; and of the succeeding Beaufort beds, characterised by yellow sandstone bands parted by blue and green shales, mud-stones and flag-stones, at least several thousand feet thick.

The Acrolepis may have come from either the Dwyka or the Ecca shales, and it is interesting in this connection to note that scales belonging to this genus have been obtained close to the summit of the Ecca shales near Ladysmith, Natal.*

Conspicuous sandstones are not known to occur in the Ecca beds of the northern Cape of Good Hope, and the sandstone inclusions are therefore in all probability from some horizon in the Beaufort beds-a view which is supported both by the fossils described below and by the small endothiodont reptile, Chelyoposaurus williamsi, Broom, found in Wesselton Mine. $\dagger$

The inclusions probably fell down into the pipes and were there preserved while denudation removed all traces of the parent rocks over the locality in question.

* Annals Natal Museum, 2, 2, 1910, 227 and 229. 259.

† Records Albany Museum, 1, 3, 1904, 15, 4, and Trans. S.A. Phil. Soc., 154, 1905, 
The fishes, as well as the reptile, are now preserved in the McGregor Museum, Kimberley.

Acrolepis addamsi, sp. $\mathrm{n}$.

(Plate XX.)

This species is founded on a number of fragmentary fishes crushed together on a small slab of shaly sandstone found in Wesselton Mine on the $135 \mathrm{ft}$. level.

Though of the five fishes four are almost certainly the same species, to avoid any possible confusion the largest specimen will be regarded as the type.

Though it is impossible to ascertain the length of the species, we may, I think, safely assume that it was half as large again as the type of Acrolepis ortholepis, Traquair, figured by Traquair, and further that the body was relatively deeper.

The dorsal fin consists of about 32 rays, all jointed, and the posterior ones at least branched distally.

The pectoral and pelvic fins are only seen on a smaller specimen, which may possibly not be the same species, and to avoid confusion I think it better to leave out the description.

The anal fin is very large and powerful and has about 55 rays. All are jointed and mostly bifurcated.

The caudal fin is large and bifurcated, but not very deeply. The rays are very numerous and distally branched. Fulcra are present along the lower border. A series of long narrow median scales form the upper riảge.

The scales of the middle of the body have a series of flat ridges passing obliquely backwards and anastomosing. The posterior border of the scales is denticulated with about 6 or 7 blunt serrations. The scales are quite unlike that figured by Smith Woodward as the type of Acrolepis digitata.

I have pleasure in dedicating this species to Mr. C. E. Addams, sometime manager of Wesselton Mine.

\section{Disichthys kimberleyensis, g. et sp. $n$.}

\section{(Plate XXI.)}

The type of this new genus and species is one of 6 or 7 fossil fishes on a slab of soft sandstone found in the De Beers Mine tip.

The fishes represent three different species, of which two are sufficiently well preserved for description. Both are very distinct new types, and must be placed, in my opinion, in new genera. 


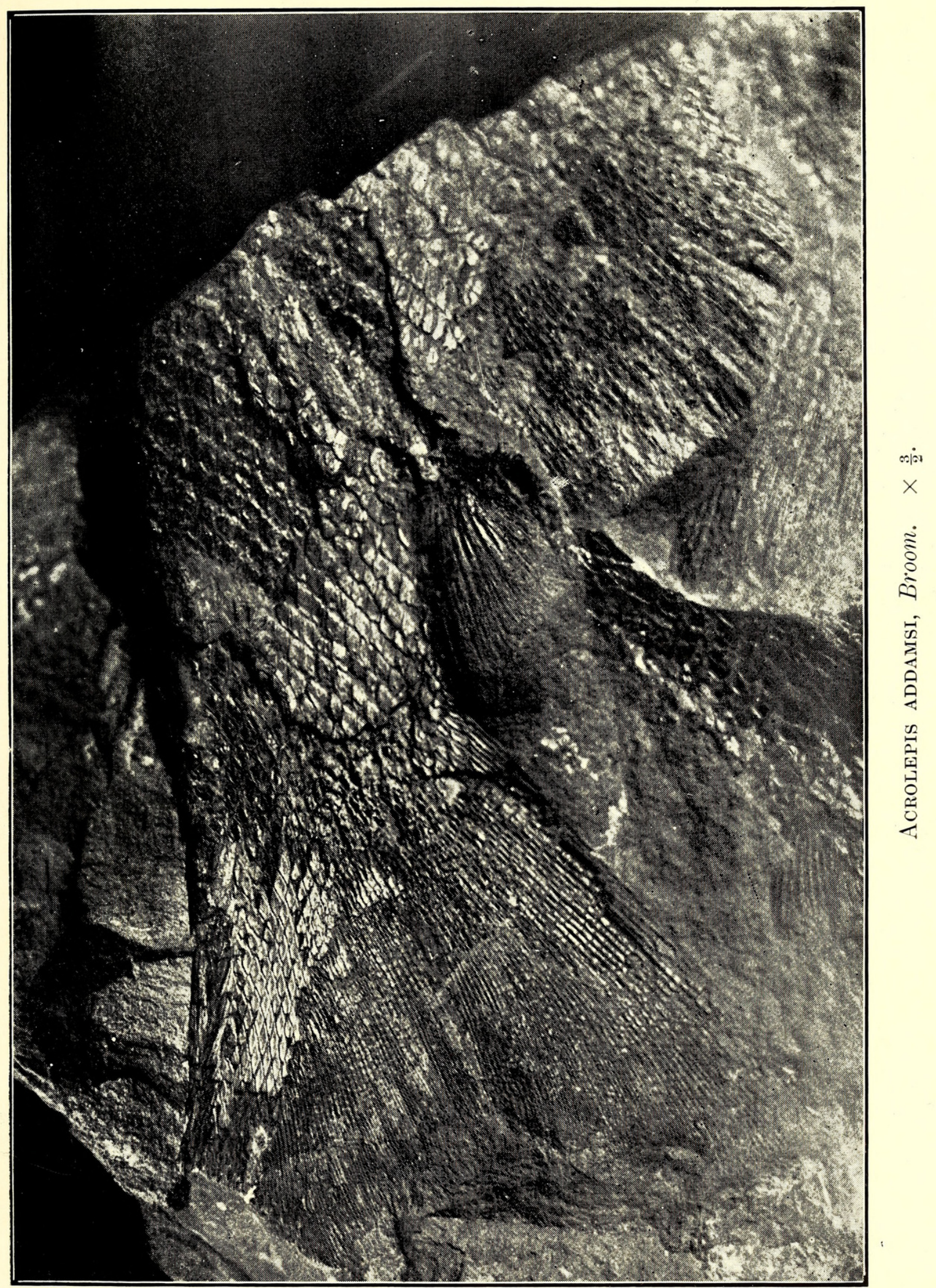

West, Newman. 



\section{$2 \mathrm{BHL}$ Biodiversity Heritage Library}

Broom, Robert. 1913. "ON SOME FOSSIL FISHES FROM THE

DIAMOND-BEARING PIPES OF KIMBERLEY." Transactions of the Royal Society of South Africa 3, 399-402. https://doi.org/10.1080/00359191309519707.

View This Item Online: https://www.biodiversitylibrary.org/item/182860

DOI: https://doi.org/10.1080/00359191309519707

Permalink: https://www.biodiversitylibrary.org/partpdf/175525

\section{Holding Institution}

Smithsonian Libraries

\section{Sponsored by}

Biodiversity Heritage Library

\section{Copyright \& Reuse}

Copyright Status: Not in copyright. The BHL knows of no copyright restrictions on this item.

This document was created from content at the Biodiversity Heritage Library, the world's largest open access digital library for biodiversity literature and archives. Visit BHL at https://www.biodiversitylibrary.org. 